\title{
INTERACTIVE BUMPER ANIMATION PADA ANDROID UNTUK MENINGKATKAN EFEKTIVITAS MEDIA PROMOSI
}

\author{
Maulid Agung Triono ${ }^{1}$ | Dodot Sapto Adi ${ }^{2} \mid$ Saudah $^{2}$
}

${ }^{1}$ Program Studi Manajemen, Fakultas Ekonomi dan Bisnis, Universitas Merdeka Malang 2Program Studi IImu Komunikasi, Fakultas IImu Sosial dan IImu Politik, Universitas Merdeka Malang Jalan Terusan Raya Dieng 62-64 Malang, 65115

\section{Correspondence}

Maulid Agung Triono

Program Studi Studi Manajemen, Fakultas Ekonomi dan Bisnis, Universitas Merdeka Malang Email: maulid.agung@unmer.ac.id https://doi.org/10.26905/nomosleca. v7i1.5567

\begin{abstract}
This study describe dynamics of educational promotion activities, by utilizing creative content technically continuously developed through Androidbased smartphone media. Technological innovation is an unavoidable demand, and along passing with regulation of The Minister of Education Culture. IBA (interactive bumper animation), which is a creative content product, with a process based on the principle of integration of animation and video products, can be ascertained to be the best alternative to increase the effectiveness of promotional media. This descriptive and applied approaches research, involving nine internal and three external informants who understand digital technology. The results formulate an ideal concept for producing content, and then create a prototype that accessed via Android-based smartphone. Creative content development by utilizing applications can support promotional performance; CC 2017, adobe audition 6, 3DSMax, edius7, Lumion 9 dan 3D Vista.
\end{abstract}

Keywords: Promotion Effectiveness; Android Smartphone, IBA

\begin{abstract}
Abstrak: Dinamika promosi pendidikan, memanfaatkan konten kreatif dikembangkan melalui media smartphone berbasis android. Inovasi teknologi menjadi tuntutan seiring dengan bergulirnya Permendikbud. IBA (interactive bumper animation) produk konten kreatif dilandasi prinsip integrasi produk animasi dan video, menjadi alternatif untuk meningkatkan efektivitas media promosi. Penelitian dengan pendekatan deskriptif dan terapan, melibatkan delapan internal dan tiga eksternal informan memahami teknologi digital. Hasil penelitian merumuskan konsep ideal memproduksi konten, membuat prototype diakses melalui media smartphone android untuk mendukung promosi: adobe after effect CC 2017, adobe audition 6, 3DSMax, edius7, Lumion 9 dan 3D Vista.
\end{abstract}

Kata Kunci: Efektivitas Promosi; Smartphone Android, IBA. 


\section{1 | PENDAHULUAN}

Perguruan Tinggi Swasta (PTS) secara kreatif telah menerapkan berbagai strategi, dengan memposisikan promosi pendidikan sebagai program kerja inti rutin tahunan, dan selanjutnya menentukan pencapaian jumlah minimum penerimaan mahasiswa baru setiap tahun. Media promosi pendidikan berbasis teknologi kreatif menjadi tumpuan terwujudnya harapan tersebut, yaitu dengan melakukan optimalisasi kinerja dalam menghadapi kompetisi bersifat global, karena era saat ini menuntut PTS nasional untuk memberi kesempatan luas bagi masyarakat untuk memperoleh pendidikan yang layak, baik kepada masyarakat di lingkup domestik maupun berasal dari luar negeri.

Pada prinsipnya dapat dirumuskan, bahwa dengan memiliki keunggulan manajemen media promosi berbasis teknologi kreatif, akan memiliki kesempatan yang lebih terbuka untuk mencapai tujuan, bahkan lebih siap untuk menyeleksi dalam rangka memperoleh mahasiswa baru yang unggul, dan pastinya dapat diharapkan pula meraih dampak yang signifikan meningkatkan citra kelembagaan bagi perguruan tinggi tersebut. Sebagaimana diungkapkan dalam hasil studi (Saudah, 2020), bahwa dengan memanfaatkan teknologi kreatif justru manajemen promosi mampu mengendalikan pesan-pesan yang sepatutnya disampaikan kepada masyarakat luar kampus, dan juga dipastikan membawa perubahan yang diharapkan, disamping dapat dipertanggungjawabkan secara kelembagaan.

Bergulirnya kebijakan pemerintah melalui Permendikbud Nomor: 3-7 Tahun 2020 yang mendasari penyelenggaraan Program Belajar Kampus Merdeka, semakin memberi ruang yang leluasa bagi manajemen perguruan tinggi untuk melakukan inovasi, khususnya dengan upaya memanfaatkan teknologi komunikasi untuk membuat konten-konten kreatif-positif, berupa informasi layak saji yang terus dikembangkan sesuai kepentingan kampus. Namun sebaliknya mengenai pentingnya kebutuhan informasi bagi masyarakat luar kampus, sudah seharusnya menjadi faktor pendorong untuk melakukan inovasi secara berimbang, artinya proses penyebaran informasi selayaknya mempertimbangkan kemudahan untuk memperolehnya. Hal ini seperti yang diungkapkan dalam hasil studi (Triono, 2019), bahwa sangat penting memahami karakter masyarakat dunia maya yang membutuhkan informasi, karena proses selektivitas media sudah dipastikan bergulir mendahului keputusan untuk memperoleh informasi, sehingga memunculkan metode yang selalu diperbarui untuk memastikan kualitas dan konsistensi desain informasinya.

Disini terdapat dua pertimbangan mendasar dalam kerangka promosi pendidikan tinggi. Pertama, difusi informasi sebaiknya mempertimbangkan 
pemanfaatan media berbasis teknologi kreatif, disesuaikan dengan aplikasi yang secara umum digunakan masyarakat misalnya terkait dengan sosial media (facebook, instagram, twitter dan sebagainya). Kedua, semudah mungkin dapat dipahami kontennya (foto, video, animasi, copy writing, dan sebagainya), sehingga menimbulkan rasa nyaman audiens untuk menuntaskan sajian informasinya. Pertimbangan tersebut sejalan dengan hasil studi (Adi \& Pandalu, 2017), bahwa hadirnya inovasi teknologi seperti rekayasa aplikasi yang terintegrasi dalam strategi cybernetic marketing public relations, karena pada dasarnya secara maksimal dapat digunakan untuk penyebarluasan informasi, dengan menampilkan konten-konten menarik dilengkapi permainan tambahan yang menyenangkan, sehingga lebih dijamin dapat memberi kontribusi tinggi terhadap program promosi pendidikan tinggi, bahkan berdampak signifikan terhadap segala bentuk upaya untuk meningkatkan citra lembaga pendidikan itu sendiri dalam jangka waktu yang relatif panjang.

Keputusan dari manajemen promosi memiliki peran penting dalam menentukan target promosi. Adapun target promosi dapat dilihat berdasarkan segmentasi, pemilihan prioritas terbaik media yang digunakan. Selain itu juga ada penetapan materi sebagai konten yang harus ditampilkan, solusi alternatif terbaik untuk mengatasi hambatan yang ditemukan. Langkah terakhir adalah upaya meningkatkan keberhasilan secara berkesinambungan. Ada beberapa cara yang dapat dilakukan untuk menunjang promosi, antara lain direct marketing, advertising, personal selling, sales promotion dan juga peran public relations (E. A. Sari \& Wijaya, 2020) Kondisi seperti ini juga ditemukan melalui hasil studi (D. Sari \& Dwiya, 2018) bahwa semakin baik media digital yang digunakan untuk kegiatan pemasaran akan semakin menarik minat konsumen untuk memanfaatkannya. Sebenarnya keputusan konsumen menggunakan media, juga ditentukan seberapa canggih tawaran teknologi yang sudah diselaraskan dengan karakteristik konsumen seperti kebiasannya, gaya hidupnya, dan tuntutan kebutuhannya bisa terpenuhi.

Memperhatikan kembali jumlah penerimaan mahasiswa baru yang semakin meningkat setiap tahunnya, begitu pula dengan sebaran asal daerah mahasiswa, maka akan berlanjut terus program penyempurnaan manajemen promosi yang bertumpu pada media interaktif, karena bisa diakses melalui berbagai media sosial. Disamping itu juga dimanfaatkan untuk sarana menemukan informasi, dan untuk mendukung aktivitas penyebarluasan informasi pendidikan tinggi secara efektif. Kondisi seperti juga diungkapkan dalam studi yang dilakukan oleh (Puspitarini \& Nuraeni, 2019), bahwa sekitar 49 persen dari populasi penduduk Indonesia merupakan pengguna aktif media sosial. Dengan mengutip hasil riset We Are Social, menunjukkan diantaranya yang paling diminati adalah youtube, facebook, instagram, dan twitter. Selanjutnya dengan merujuk pada informasi dari (Hamdan, 
2019), bahwa Indonesia menduduki peringkat ke 4 dunia berdasarkan jumlah pengguna instagram, bahkan menurut perusahaan NapoleonCat yang berpusat di Warsawa mencatat penggunanya mencapai 61.610 .000 per November 2019.

Disinilah konten kreatif dalam media promosi Universitas Merdeka Malang berbasis android pada perangkat smartphone, perlu untuk dikembangkan dengan mengintegrasikan produk animasi dan video yang disebut IBA (interactive bumper animation) dalam penyampaian informasi pendidikan. Ini merupakan inovasi rekayasa konten yang dapat menimbulkan daya tarik tersendiri, baik sebagai produk dari inovasi teknologi secara terintegrasi, maupun penempatan operasi sistemnya yang menggunakan android, yaitu untuk mempercepat transaksi informasi kepada sasaran promosi. Hal ini memberikan arah yang pasti, bahwa konten promosi yang diintrodusir dengan animasi flash, dapat diposisikan sebagai pintu utama bagi konten inti berisi informasi pendidikan yang direkayasa dalam bentuk video highlight. Kelebihan inovasi ini dapat mempresentasikan secara otomatis maupun interaktif, dan untuk memperkuat atraktifnya disisipkan unsur multimedia dalam bentuk suara, gambar maupun panel yang mudah dijalankan (Puspitosari, 2010).

Urgensi penelitian ini diarahkan untuk menentukan terapan IBA pada sistem pengoperasian android yang digunakan sebagai media promosi, dengan berbasis rekayasa teknologi digital secara terintegrasi, didukung inovasi konten kreatif yang diproduksi berdasarkan opini aspiratif yang berimbang, bersumber dari pelaku promosi internal kampus yang melibatkan dosen dan mahasiswa Universitas Merdeka Malang secara terpilih. Hasil rumusan secara konseptual dari kegiatan menjaring opini tersebut, akan menjadi pertimbangan untuk menentukan langkahlangkah teknis dalam membuat prototype.

Ini merupakan proses untuk mencapai standar awal output penelitian yang harus dicapai, dan selanjutnya melakukan konfirmasi kepada beberapa siswa yang memahami multimedia, dalam rangka memperoleh kepastian sebagai produk inovasi media promosi, sehingga dapat dipertimbangkan memenuhi syarat representatif dalam rangka mencapai kelayakan pengoperasian aplikasinya. Untuk itu kegiatan penelitian diarahkan mengamati secara mendalam, dan selanjutnya menggambarkan realitas sosial yang meliputi berkesadaran memasuki ruang kompetisi di era 4.0 pada pelaksanaan promosi, tindakan rasional upaya melakukan inovasi media promosi, dan upaya meningkatkan citra kelembagaan melalui produksi konten-konten kreatif.

\section{2 | METODE PENELITIAN}

Penelitian ini menggunakan pendekatan post-positivisme, dengan selalu menempatkan setiap realitas sosial sebagai temuan yang bernilai holistik-integratif, 
dan apabila ditemukan hubungan setiap gejala sosial yang ada, merupakan dinamika sosial yang tumbuh dan berkembang secara berkelanjutan. Demikian pula mengenai proses koleksi dan analisis data, dapat dilaksanakan secara berkesinambungan sesuai dengan kebutuhan kegiatan penelitian. Sifat interaktif ini dipertahankan sampai tercapainya output penelitian, agar setiap saat dapat melakukan konfirmasi hasil rumusan analisis.

Adapun tahapannya mengadopsi arahan Cresswell (2002) yang meliputi: 1) pengorganisasian data yang diperoleh dari hasil kegiatan pengamatan maupun wawancara; 2) mengikuti alur decoding data untuk menata informasi yang dinilai sangat penting; 3) mencari penguatan dari sumber-sumber yang sama maupun berbeda untuk memahami informasi; 4) memisahkan beberapa informasi yang kurang memiliki kaitan kuat dengan fokus penelitian; 5) mendeskripsi secara terinci pengalaman informan dalam bentuk opini mengenai pemanfaatan media promosi; dan 6) menyusun rumusan akhir dengan pendekatan induksi untuk rekomendasi pembuatan aplikasi dan konten kreatif media promosi.

Sesuai dengan lingkup penelitian yang sudah ditetapkan pada kesadaran pelaksana manajemen promosi memasuki ruang kompetisi, upaya melakukan inovasi teknologi pada media promosi, dan alternatif solusi memproduksi kontenkonten kreatif, maka dapat dipastikan kegiatan lebih mengarah kepada bentuk penelitian terapan. Lokasi penelitian secara cermat disesuaikan dengan kebutuhan tanpa menentukan unit tertentu, agar dapat memenuhi seluruh proses yang sudah ditetapkan meliputi ruang internal dan eksternal kampus. Prinsip fleksibilitas menjadi penting, mengingat sifat keberlanjutan untuk memperoleh output berupa prototype desain media promosi Universitas Merdeka Malang.

Tahap pertama penentuan informan sebagai subjek inti penelitian, telah diperoleh sebanyak 3 orang dosen serta 6 orang mahasiswa, dan semua informan inti merupakan pengiat promosi pada lingkup program studinya masing-masing. Persepsi yang tumbuh dilandasi pengetahuan dan pengalaman masing-masing, dan persepsi ini sebagai investasi awal yang digunakan untuk mengawali rekayasa teknologi yang diterapkan pada konten kreatif media promosi. Produksi konten pada media, telah dilakukan secara berulang melalui rekayasa bersifat terperinci, didasarkan hasil analisis melalui proses moderasi dalam forum FGD, sehingga dapat diperoleh kesepakatan bersama sebagai pertimbangan menuju tranformasi perangkat, yaitu media promosi menggunakan pola IBA ke dalam perangkat smartphone berbasis android. Tahapan kedua, merupakan pengembangan dari hasil implementasi rekayasa konten kreatif IBA yang sudah berbentuk produk terintegrasi animasi videografi. Untuk memenuhi tahapan yang arah kegiatannya jaring opini pada siswa SMK, telah diperoleh informan sebanyak 3 orang sebagai representasi dari target sasaran promosi pendidikan Universitas Merdeka Malang, 
dan sekaligus dinilai memiliki pengetahuan mengenai multimedia interaktif.

\section{HASIL DAN PEMBAHASAN}

\section{Media Promosi Era 4.0}

Memasuki masyarakat ekonomi era 4.0 telah menyadarkan setiap unsur pelaksana manajemen promosi, selalu memposisikan good relationship approach sebagai tindakan utama yang tidak boleh ditawar-tawar. Mengikuti perkembangan promosi yang dilaksanakan Universitas Merdeka Malang sejak 3 tahun terakhir, dengan kebijakan strategis yang tampak disempurnakan secara berkesinambungan dipastikan untuk meraih posisi terbaik, bahkan berupaya memperkuat reputasi melalui program peningkatan kualitas sumberdaya internal, dan meningkatkan citra kelembagaan melalui penyebarluasan informasi pelaksanaan program pendidikan yang dipastikan dapat memenuhi kebutuhan masyarakat.

Perencana kegiatan promosi semakin menyadari, bahwa kondisi tersebut satu sisi merupakan tantangan yang harus dihadapi, namun sisi lain justru menjadi peluang sangat terbuka untuk melakukan kegiatan promosi pendidikan itu sendiri. Beberapa informan kunci juga memberikan gambaran mengenai kegiatan promosi, terutama yang dilakukan pada tingkatan promosi program studi memberikan pandangan, bahwa masa pandemi menjadi uji kemampuan mempertahankan reputasi dalam arena promosi pendidikan, dengan menyiapkan pendekatan media baru sebagai solusi terbaik untuk meningkatkan citra positif kelembagaan.

Kondisi ini juga terjadi pada pengalaman 9 informan dalam melaksanakan kegiatan promosi, secara keseluruhan telah menyadari pentingnya kreativitas dalam menyalurkan informasi pendidikan, yaitu pada saat menyampaikan programprogram yang ditawarkan kepada masyarakat, baik dengan metode tatap muka maupun melalui media online sesuai dengan pertimbangan rating. Bahkan pada beberapa lokasi sasaran promosi pendidikan, terutama kota-kota yang lebih menunjukkan karakter metropolis, ternyata ditemukan realitas sosial yang selalu mengedepankan gaya hidup post-modernist.

Biasanya tertuju pada persoalan akreditasi maupun posisi hasil pemeringkatan perguruan tinggi, sehingga perlu keberanian besar untuk mengungkap keunggulan komparatif yang dimiliki Universitas Merdeka Malang. Memasuki lembaga pendidikan tinggi tertentu cenderung diukur sebagai komodifikasi terhadap dirinya sendiri, dalam rangka menentukan posisi atau status sosialnya agar dipandang lebih bermartabat. Gaya hidup post-modern ini seperti yang diungkapkan (Suyanto, 2014), bahwa masyarakat metropolis yang posmodern dalam realitasnya merupakan masyarakat konsumen, yaitu menilai penting untuk selalu 
memperlihatkan identitas sosialnya.

Informasi mengenai keunggulan komparatif yang sudah disebarluaskan pelaksana promosi pendidikan (Kemendikbud.go.id, 2020), salah satunya dengan mengadopsi hasil klasterisasi perguruan tinggi yang dilaksanakan Dirjen Dikti Kemendikbud RI. Universitas Merdeka Malang memperoleh peringkat ke 49 yang dinilai berdasarkan produktivitas pelaksanaan tridharma perguruan tinggi, dan pemeringkatan tersebut diharapkan dapat mendorong kinerja kelembagaan menjadi lebih baik pada masa yang akan datang (Unmer.ac.id, 2020). Penyebaran informasi secara masif perlu dilakukan, dalam rangka memasuki ruang kompetisi yang rasional dan terukur, termasuk mempertimbangkan pemanfaatan media promosi dan rekayasa konten kreatifnya.

Dunia pendidikan perlunya memanfaatkan media sosial menjadi pilihan utama untuk diunggulkan sebagai saluran penyebarluasan informasi. Website, youtube, whatsapp, facebook, instagram dan sebagainya, merupakan sistem operasi digital yang dapat dijangkau dengan mudah melalui perangkat smartphone berbasis android. Kondisi senada juga ditemukan dari hasil studi (Ratna Gumilang, 2019), bahwa manfaat yang paling dirasakan atas penggunaan media tersebut, adalah terjadinya komunikasi langsung atau real time secara efektif dan efisien. Disamping itu juga bisa berbagi gambar maupun material-material dalam bentuk lain yang bervariasi, juga secara intensif menampilkan informasi terbaru sesuai kebutuhan.

Rekayasa media promosi Universitas Merdeka Malang sudah menggulirkan banyak informasi, baik yang menggunakan media bersifat konvensional maupun digital, dengan berbagai konten yang mengusung kemanfaatan dan keunggulan. Dari sinilah daya tarik yang ditampilkan pada media, akan menjadi alternatif daya tawar yang menggambarkan perolehan kehidupan lebih baik, terutama melalui posisi peserta didik di masa yang akan datang. Gambaran masa depan yang berdampak positif dalam upaya memperoleh status sosial ekonomi, merupakan proses persuasi yang mengubah segala sesuatunya menjadi investasi jangka panjang.

Kondisi ini dapat disebut sebagai dampak berkelanjutan, melalui tahapan sangat jelas yang dapat dijangkau melalui komitmen dalam pelaksanaan pendidikan. Problem terbesar promosi yang dihadapi perguruan tinggi secara menyeluruh, baik yang berhubungan dengan lingkungan internal maupun eksternal, terletak pada ketersediaan informasi yang relatif lengkap, terbaru serta mudah untuk memperolehnya. Disinilah reputasi dipertaruhkan pada keunggulan manajemen, dengan mengutamakan pelayanan informasi yang mengikuti dinamika kebutuhan, dan didukung penyesuaian perangkat teknologi komunikasi selaras dengan yang digunakan masyarakat. 


\section{Media Digital Android}

Perangkat media sosial yang menjadi primadona masyarakat, mempertimbangkan kemudahan dalam memperoleh informasi, meletakkan pilihannya kepada smartphone yang di dalamnya tersedia operating system android. Sedangkan konten kreatif yang diharapkan dapat memenuhi kebutuhan, setidaknya memenuhi syarat menjangkau secara luas dengan didukung daya tarik pada penayangan informasinya. Basis multimedia yang memuat esensi daya tarik melalui gambar, teks, warna serta gerakan, menjadi sangat penting dalam menumbuhkan persepsi positif sasarannya, dan selanjutnya berdampak signifikan terhadap citra perguruan tinggi.

Demikian disadari oleh informan yang sudah melaksanakan kegiatan promosi, terutama kemudahan dari hasil pemanfaatan multimedia pada sistem android. Informan juga menegaskan, bahwa sebenarnya kegiatan promosi bisa dilakukan seluruh warga kampus tanpa terkecuali termasuk mahasiswa, disamping jumlahnya terbesar juga memiliki perangkat modern era digital. Potensi ini akan semakin besar untuk memberikan kontribusi bagi program promosi Universitas Merdeka Malang, yaitu melalui perangkat smartphone berbasis android yang sangat handal untuk memasuki ruang sosial media dalam bentuk apapun.

Hal ini juga sejalan dengan inovasi yang sudah dilakukan oleh Universitas Merdeka Malang dalam kegiatan promosi bermedia, khususnya transformasi secara terintegrasi sudah dilakukan melalui tahapan yang pasti dalam bentuk audio visual digital. Disinilah prinsip inovasi tanpa henti selalu diterapkan, dengan menghadirkan insan-insan kreatif dari lingkungan internal kampus, untuk berkontribusi secara terbuka baik melalui pendekatan yang sifatnya konseptual kritis maupun teknis digital. Dilandasi observasi mengenai kesadaran berinovasi pada diri pelaksana promosi, bahwa mengakui masih perlunya meningkatkan intensitas kegiatan promosi berbasis media interaktif yang dapat dijangkau oleh smartphone.

Selanjutnya juga menerangkan tentang sasaran promosi terbesarnya dari golongan remaja terpelajar (SMA/SMK), dengan kecenderungannya yang selalu ingin memperoleh kemudahan dalam pencarian informasi, maka inovasi dalam media promosi juga harus mampu menjawab tantangan tersebut. Dirasakan msaih perlu menyajikan informasi yang lengkap dan padat, namun masih mengharuskan untuk selalu menampilkannya dengan didukung sentuhan artistik, sehingga menimbulkan bentuk keunikan tertentu yang dapat berdampak positif terhadap penerimaan.

Penggunaan secara maksimal perangkat digital smartphone berbasis android menurut pengalaman informan, bahwa kegiatan promosi dapat dilaksanakan tanpa batas waktu, apalagi pada perjalanan waktu setahun belakangan ini dirasakan 
menjadi lebih mudah, karena masa pandemi memungkinkan untuk menjangkau secara efektif. Bahkan dampaknya diibaratkan untuk menjadi terbiasa menyajikan konten positif yang unik, dengan semaksimal mungkin memanfaatkan fitur-fitur yang relevan dengan sasaran promosi. Beberapa informan dari kalangan mahasiswa menerangkan, bahwa ada keuntungan tersendiri kalau kegiatan promosi dilakukan dari rumah (work from home).

Menurutnya disamping dapat melakukan posting informasi kegiatan pribadi, juga dapat diperkuat dengan latar visual lingkungan kampus yang sudah tersedia cukup banyak dalam bentuk templates. Terdapat sedikit upaya untuk mengkonstruksi adanya little-drama berlatar gedung kampus, dan dapat diperkuat dengan tampilan visual gaya hidup anak muda. Kondisi ini seperti juga ditemukan melalui hasil studi (Ida et al., 2020), bahwa dalam rangka optimalisasi peningkatan pelayanan bagi mahasiswa baru, sangat diperlukan media interaktif berbasis android dalam bentuk aplikasi, untuk mempermudah mengakses informasi yang juga difasilitasi dengan satu menu konsultasi interaktif melalui media whatsapp, telephone call, dan facebook. Hal ini dinilai sangat penting dilakukan, agar calon mahasiswa baru akan memperoleh kemudahan dan merasa terbantu dengan bentuk pelayanan yang efektif dan efisien.

\section{Konten Kreatif IBA}

Penentuan media yang dinilai memiliki kemudahan untuk menjangkau target promosi pendidikan tinggi, adalah yang memiliki basis inovasi teknologi multimedia dengan didukung konten kreatif, dan disinilah produk kolaborasi dalam bentuk videografi dan animasi memiliki probabilitas yang tinggi. Produk ini merupakan alternatif yang bisa dimunculkan, setelah peneliti menyodorkan sebuah gagasan konten kepada informan, kemudian memperoleh respon empirik yang merujuk kepada upaya bersama, yaitu untuk membuat sebuah rekayasa konten yang lebih kongkrit. Diskusi semakin berkembang dengan informan yang rata-rata memiliki karakter visual, maksudnya memiliki kemampuan merancang konten secara grafis digital, sehingga mampu memberikan ilustrasi secara detail dalam bentuk storyboard maupun schene builder.

Secara terstruktur juga merumuskan setiap ide cerita yang sesuai dengan realitas nyata, walaupun karakter-karakter yang dimunculkan merupakan produk dari perubahan ide aslinya. Disinilah sebenarnya keunggulan penyertaan karya konten dalam bentuk animasi, apabila diintegrasikan dengan informasi pendidikan yang disajikan dalam bentuk videografi. Keunggulan konsep integrasi produk konten seperti ini juga ditemukan pada studi (Adi et al., 2018) yang menyatakan, bahwa hampir seluruh produk animasi dilandasi oleh fanatisme yang tinggi terutama di 
bidang teknologi 3 dimensi (3D), yaitu dengan menampilkan karakater yang sangat kuat sebagai identitas karya seni (brand product) individu dan komunitasnya, sehingga mudah menunjukkan derajat adaptasinya terhadap kemajuan teknologi.

Bagi sebagian besar informan menyetujui pendekatan konsep tersebut, karena lebih memberi kemudahan bagi manajemen promosi pendidikan tinggi maupun pelaksana promosi pada lingkup program studi. Media promosi harus sengaja disajikan untuk bisa dinikmati secara meluas, dan juga direkayasa melalui berbagai fasilitas digital yang dinilai menarik perhatian, karena juga mengajak audiens untuk tetap betah menuntaskan seluruh informasi yang ada. Kekhususan dari konten kreatif pada media promosi efektif, juga selalu dituntut untuk dapat meningkatkan jumlah pengunjung, sehingga disamping memberikan persuasi yang kuat juga mampu mendorong tumbuhnya rasa penasaran.

Konsep dalam bentuk produk prototype detail konten terintegrasi sudah dirumuskan, selanjutnya dilakukan konfirmasi kepada sampel sasaran promosi dalam bentuk kelompok kecil, yaitu diwakili oleh remaja pelajar yang juga memahami konten-konten kreatif media promosi, sehingga kegiatan studi semakin memperoleh kepastian mengenai keunggulan dan kekurangannya. Untuk itu penyelenggaraaan kegiatan kelompok diskusi terarah (FGD), sangat berpeluang menemukan alternatif solusi untuk memperbaiki produk konten promosi yang sesuai dengan harapan, agar penyempurnaan konten dapat mengarah kepada faktorfaktor teknis yang semakin terinci.

Mengindahkan pertimbangan-pertimbangan yang konstruktif mengenai konten kreatif, dapat dikemas dalam bentuk produk terintegrasi yang bersifat interaktif menggunakan animasi dan video. Interaksi yang digunakan adalah pendekatan konten statis dan dinamis. Konten statis di kemas dalam bentuk video animasi 3 dimensi dari objek promosi. Animasi 3 dimensi digunakan untuk memberikan sentuhan awal yang tajam, sehingga durasi yang disediakan dapat memberikan kenyamanan bagi audiens yang menelusuri informasi inti yang dibutuhkan. Disinilah dapat ditentukan fungsi utama animasi tersebut sebagai interactive bumper animation (IBA), yaitu menjadi jembatan yang memanjakan audiens untuk memenuhi kebutuhannya akan informasi. Hal ini sesuai dengan hasil studi yang dilakukan oleh (Lingga et al., 2020), bahwa tampilan animasi dapat menembus ruang waktu, artinya antara penyaji dan audiens tidak perlu berada pada tempat dan waktu yang sama, bahkan dalam penyajiannya memunculkan estetika tinggi dengan menggunakan prinsip appeal yang direpresentasikan melalui karakter agar menarik perhatian.

Konten dinamis di kemas dalam bentuk simulasi ruang virtual yang memberikan ruang kepada user untuk menelusuri informasi yang dibutuhkan secara mandiri dengan menggunakan konten foto panorama yang memiliki keunggulan visual 360 
derajat. Ruang virtual disimulasikan sebagai etalase yang menjadi display konten video yang dapat dioperasionalkan secara interaktif. Konten informasi dengan video digunakan untuk penataan informasi yang mampu bercerita mengenai fasilitas maupun aktivitas pendidikan, mudah untuk diakses dalam situasi apapun, disusun secara runut terperinci informasinya, padat dengan tampilan visual menarik, dan dilengkapi pesan-pesan yang mudah untuk dipahami. Audio sebagai musik latar digunakan untuk memberikan penguatan penerimaan pada memori audiens, dengan harapan semakin tinggi penerimaan terhadap visual grafis pada diri audiens, maka akan semakin terbuka penerimaan audiens terhadap informasi, dan berdampak pada semakin lamanya informasi akan mengendap pada memori audiens.

Adapun pada tahap ini meliputi: 1) kegiatan analisis hasil jaring opini dengan menggunakan pengujian secara fungsional untuk memperoleh simpul adaptasi teknologi dan konten kreatif; 2) reka ulang ke dalam bangunan media digital untuk memperoleh sinkronisasi terbaik diantara teks, grafis, sound, sampai dengan motion; 3) menentukan kesesuaian panel-panel information-based dengan game interactive yang disediakan; 4) melakukan konfirmasi untuk menemukan standar minimum daya tarik media promosi; dan 5) selanjutnya dilakukan secara berulang sampai pada akhirnya menentukan hasil akhir.

Berdasarkan langkah-langkah tersebut dapat dipastikan mengenai kebutuhan konten promosi yang diharapkan, sehingga segera disusun format input-output untuk menuntun perancangan program yang dalam bentuk prototype audio visual. Tahap teknis pertama, lebih mengupayakan terselesaikannya produk halaman antarmuka (interface), yaitu berisikan bumper animasi 3D sebagai visual pembuka atraktif yang memiliki daya stopping power bagi user yang diproduksi dengan aplikasi 3DSMax, Lumion dan Adobe After effect CC 2017. Tahap kedua, pembuatan ruang virtual yang menampilkan panel-panel menu utama dan sub menu, sehingga audien bisa dengan mudah memasuki ruang informasi inti. Disinilah penggunaan secara maksimal aplikasi 3DSMax, Lumion dan 3DVista. Tahap teknis ketiga dikonsentrasikan untuk memproduksi video profil universitas maupun program studi, yaitu sebagai tampilan informasi inti penyelenggaraan pendidikan dengan menggunakan aplikasi Edius 7, Adobe After effect CC 2017 dan Adobe Audition 6. Tahap terakhir yaitu menentukan navigasi dan hot spot display konten video pada ruang virtual dengan menggunakan 3DVista termasuk didalamnya proses publishing.

Tampilan video yang diperkuat dengan latar audio jingle yang telah disediakan, ataupun jingle program studi yang diproduksi menggunakan aplikasi adobe audition 6 dan fruityloop, diharapkan dapat menumbuhkan kenyamanan audiens untuk menuntaskan informasi yang disajikan. Penggunaan aplikasi edius7, Adobe After 
effect CC 2017, 3DSMax, Lumion dan 3DVista dapat memberi fasilitas teknis, khususnya dalam proses mengkonstruksi konten kreatif yang dibutuhkan, karena menyediakan variasi efek editing maupun plug-in yang bisa bekerja secara efektif sampai dengan rendering. Atas dasar deskripsi tersebut, IBA (interactive Bumper animation) dapat dipastikan menjadi model konten kreatif terbaru mewarnai media promosi Universitas Merdeka Malang, dan akan terus dengan mudah disempurnakan selaras dengan inovasi teknologi yang berkembang. Studi yang dilaksanakan secara berkelanjutan ini, melibatkan informan yang berasal dari lingkungan internal dan eksternal kampus yang memahami teknologi digital, agar dapat menghasilkan satu konsep terapan yang mengarahkan pada penyusunan prototype konten kreatif, yaitu dengan menghasilkan produk audio visual terintegrasi yang disebut dengan IBA (interactive bumper animation).

\section{4 | SIMPULAN}

Berdasarkan pembahasan dapat disimpulkan, bahwa kegiatan promosi Universitas Merdeka Malang telah dilaksanakan secara terstruktur, mulai dari tingkat manajemen pusat sampai dengan program studi. Penyebarluasan informasi dengan menampilkan keunggulan secara terintegrasi melalui visi dan misi pendidikan yang ditetapkan. Untuk itu pendekatan media baru menjadi prinsip yang mendasari operasionalnya, dengan memanfaatkan semaksimal mungkin sosial media website, youtube, whatsapp, facebook, instagram dan sebagainya, karena dapat dijangkau dengan mudah melalui penggunaan smartphone yang berbasis android. Secara khusus proses pengembangan IBA, telah dapat diselesaikan melalui tahapan antara lain: 1) penyimpulan hasil melakukan eksplorasi kebutuhan konten kreatif; 2) menyiapkan produksi konten dengan menggunakan aplikasi yang relevan; 3) membangun prototype konten secara terintegrasi; 4) melakukan konfirmasi atas prototype konten; dan 5) pengembangan konten kreatif yang dapat dijangkau media smartphone berbasis android.

\section{UCAPAN TERIMAKASIH}

Melalui jurnal ini menyampaikan ucapan terima kasih yang sebesar-besarnya, kepada Lembaga Penelitian dan Pengabdian Kepada Masyarakat (LPPM) Universitas Merdeka Malang, atas dukungan dana Hibah Internal Penelitian Dosen Pemula Tahun Pelaksanaan 2020 yang berjudul: Aplikasi Animasi Android Untuk Meningkatkan Efektivitas Komunikasi Pemasaran Universitas Merdeka Malang. 


\section{REFERENSI}

Adi, D. S., \& Pandalu, R. (2017). Efektivitas Pelayanan Informasi Internal Kampus Melalui Pemanfaatan Media Interaktif Berbasis ARTOM ( Studi Fenomenologi Pada Mahasiswa FISIP Universitas Merdeka Malang ). September, 91-100.

https://jurnalfti.unmer.ac.id/index.php/senasif/article/view/19/10

Adi, D. S., Siswanto, B., \& Hariyanto, T. (2018). Growth Approach In Alliance

The Animation Community Of Malang City. September, 10-20.

Hamdan, N. (2019, December). Pengguna Instagram di Indonesia Terbesar ke-4 Dunia. Tagar.Id. https://www.tagar.id/pengguna-instagram-diindonesia-terbesar-ke4-dunia

Ida, A., Nurohim, N., Rahman, A., \& Kusuma, A. C. (2020). Optimatimalisasi Pelayanan Penerimaan Mahasiswa Baru Berbasis Android di Politeknik Harapan Bersama Tegal. Jurnal Abdi Masyarakat Humanis, Vol 2 No $1(1), 1-7$.

http://openjournal.unpam.ac.id/index.php/JAMH/article/view/6446 Kemendikbud.go.id. (2020). Kemendikbud Sosialisasikan Lima

Permendikbud Sebagai Payung Hukum Kampus Merdeka.

https://www.kemdikbud.go.id/main/blog/2020/02/ kemendikbudsosialisasikan-lima-permendikbud-sebagai-payung-hukum-kampusmerdeka.

Lingga, G., Kusuma, A., Pasek, G., Adnyana, P., \& Bali, B. (2020). Estetika Karakter Animasi Pada Media Komunikasi Sosial. 04(01), 10-16.

Puspitarini, D. S., \& Nuraeni, R. (2019). Pemanfaatan Media Sosial Sebagai Media Promosi (Studi Deskriptif pada Happy Go Lucky House). Jurnal Common, 3(1), 71-80.

Puspitosari, H. A. (2010). Pemrograman Web Database dengan PHP dan MySQL Tingkat Lanjut " (Juli). Skripta.

Ratna Gumilang, R. (2019). Implementasi Digital Marketing Terhadap

Peningkatan Penjualan Hasil Home Industri. Coopetition : Jurnal IImiah Manajemen, 10(1), 9-14. https://doi.org/10.32670/coopetition.v10i1.25 Sari, D., \& Dwiya, K. (2018). Strategi Digital Marketing, Word of Mouth (Wom), Service Quality Terhadap Keputusan Pemakaian Jasa Go-Jek. Journal IImiah Manajemen \& Bisnis, 3(2), 188-198.

Sari, E. A., \& Wijaya, L. S. (2020). Strategi Promosi Melalui Direct Marketing Untuk Meningkatkan Jumlah Mahasiswa Baru. Jurnal IImu Komunikasi, 17(1), 16. https://doi.org/10.31315/jik.v17i1.2608

Saudah. (2020). Peer-Personality Engagement Dalam Upaya memperkuat Sinerjitas Dalam Proses Komunikasi Manajemen. Nomosleca, 6(1). https://doi.org/https://doi.org/10.26905/nomosleca.v6i1.4038 
Suyanto, B. (2014). Sosiologi Ekonomi: Kapitalisme dan Konsumsi Di Era Masyarakat Post-Modernisme. Kencana Prenadamedia Group.

Triono, M. A. (2019). Media Komunikasi Website Untuk Meningkatkan Aktivitas Bisnis. Nomosleca, 5(2).

https://doi.org/https://doi.org/10.26905/nomosleca.v5i2.3639

Unmer.ac.id. (2020). Unmer Malang Menempati Peringkat 49 Klasterisasi

Perguruan Tinggi Nasional. https://unmer.ac.id/unmer-malang-meraihperingkat-49-klasterisasi-perguruan-tinggi-nasional 